Diabetologia (1994) 37:351-357

\title{
Irreversible loss of normal beta-cell regulation by glucose in neonatally streptozotocin diabetic rats
}

\author{
K.Inoue ${ }^{1}$,M.Cetkovic-Cvrlje ${ }^{2}$,D.L.Eizirik ${ }^{2}$, V.Grill ${ }^{1}$ \\ ${ }^{1}$ Department of Endocrinology, Karolinska Hospital, Stockholm, Sweden \\ ${ }^{2}$ Department of Medical Cell Biology, Uppsala University, Uppsala, Sweden
}

\begin{abstract}
Summary Animals with NIDDM display abnormal glucose regulation of insulin secretion and biosynthesis. We tested reversibility of abnormal regulation by normoglycaemia using an islet transplantation technique. Inbred non-diabetic and neonatally STZ diabetic rats (n-STZ) were used. Transplantations insufficient to normalize the blood glucose levels (200 islets under kidney capsule) were performed from diabetic to normal (D-N) and from diabetic to diabetic (D-D), as well as from normal to normal (N-N) and from normal to diabetic (N-D) rats. Four weeks after transplantation, graft bearing kidneys were isolated and perfused with Krebs-Henseleit bicarbonate buffer to measure insulin secretion in response to $27.8 \mathrm{mmol} / 1$ glucose and $10 \mathrm{mmol} / 1$ arginine. Four weeks of normoglycaemia failed to restore glucose-induced insulin
\end{abstract}

secretion from n-STZ islets (glucose induced increment: $-1.7 \pm 2.5 \mathrm{fmol} / \mathrm{min}$ in $\mathrm{D}-\mathrm{N}, 1.2 \pm 7.1 \mathrm{fmol} / \mathrm{min}$ in D-D). In contrast to normal islets, normoglycaemia reduced insulin mRNA contents $(60 \pm 24$ in D-N, $496 \pm 119$ in D-D; O.D.-arbitrary units). However, arginine-induced secretion was markedly enhanced by diabetic environment in both normal and n-STZ islet grafts. These results indicate that selected aspects of glucose recognition are irreversibly damaged by a long-term diabetic state or, alternatively, by a lasting effect of STZ administration. [Diabetologia (1994) 37: 351-357]

Key words Animal models NIDDM, insulin secretion, insulin mRNA, cytochrome b mRNA, islets of Langerhans.
The neonatally STZ diabetic rat (n-STZ) is an animal model of NIDDM [review 1, 2]. In n-STZ insulin secretion is markedly abnormal at adult age despite only mild or moderate hyperglycaemia $[1,2]$. In particular, the insulin reponse to glucose is reduced out of proportion to the decrease in beta-cell mass. Responses to non-metabolised secretagogues, such as L-arginine or phosphodiesterase inhibitors, are however relatively preserved. This pattern of abnormalities bears resem-

Received: 1 September 1993

and in revised form: 15 November 1993

Corresponding author: Dr. V.Grill, Department of Endocrinology, Karolinska Hospital, Box 60400, S-171 76 Stockholm, Sweden

Abbreviations: NIDDM, non-insulin-dependent diabetes mellitus; STZ, streptozotocin; O.D., optical density; IRI, immunoreactive insulin blance to secretory abnormalities in human NIDDM. Regarding mechanisms behind secretory abnormalities of n-STZ previous studies have suggested that deficient glucose oxidation, possibly linked to a decreased activity of the glycerol phosphate shuttle, could underlie the lack of sensitivity to the hexose $[3,4]$.

In elucidating the primary causes behind the secretory abnormalities in n-STZ, one needs to know whether these are reversible upon normalization of the diabetic milieu. On this point available evidence is contradictory. Normalization of an insulin response to glucose was previously reported after 5 days of insulin treatment in vivo [5], or after 2 weeks of tissue culture [6]. On the other hand, Leahy et al. [7] showed that insulin treatment restored a normal glucose potentiation of responses to arginine but not a response to glucose per se. The divergent results on reversibility could possibly be due to differences in diabetes induction, with severity of diabetes increasing with injection time 
after birth [8]. This notion is compatible with the report of Serradas et al. [9]. When rats were treated with STZ on day 5 rather than day 0 after birth, the decrease in hyperglycaemia by insulin, phlorizin, or vanadate treatments failed to restore an insulin response to glucose. However, in these and in previous experiments complete normoglycaemia was not obtained.

The further elucidation of possible defects of beta cells in $\mathrm{n}$-STZ would require conclusive evidence whether or not insensitivity is present after long-term normoglycaemia. To achieve such a goal by insulin treatment is a very difficult task since a) insulin treatment rarely produces stable $24 \mathrm{~h}$ normoglycaemia b) insulin can reduce beta-cell sensitivity by direct or indirect effects [10]. In the present study we have used a transplantation procedure [11], in which islets of $n-S T Z$ were transplanted under the kidney capsule of syngeneic normal or diabetic recipients. Four weeks later we examined the insulin release from the perfused kidney as well as the expression of insulin mRNA from the grafted islets. The results were compared with those obtained in islets isolated from non-diabetic rats and transplanted into syngeneic normal or diabetic recipients.

\section{Materials and methods}

\section{Animals}

Inbred Wistar-Furth rats (B \& K, Sollentuna, Sweden) were used. Pregnant rats were delivered at mid-gestation. The day after birth newborn pups were treated with ani.p. injection of $90 \mathrm{mg} / \mathrm{kg} \mathrm{STZ}$ (kindly supplied by Dr W. E.Dulin, Upjohn, Kalamazoo, Mich., USA) as described [12]. Two days after STZ treatment blood glucose levels were measured by tail snipping. Only the pups with blood glucose levels equal or above $10.0 \mathrm{mmol} / 1$ were selected as diabetic animals. Vehicle treated pups served as normal controls. Both normal and diabetic pups were weaned around 28 days of age and allowed free access to water and a standard pelleted diet (B \& K) and were kept on a $12 \mathrm{~h}$ light $-12 \mathrm{~h}$ dark cycle.

\section{Islet isolation and transplantation}

Female rats were always used as islet donors, whereas male rats were always used as islet recipients. Before islet isolation, blood glucose levels of donor rats were measured after tail snipping. Islets of Langerhans were isolated by collagenase (Boehringer Mannheim, Mannheim, Germany) essentially as described [13, 14]. After isolation the islets were cultured 1-2 days in RPMI 1640 suplemented with $11.1 \mathrm{mmol} / \mathrm{l}$ glucose, $2.1 \mathrm{mmol} / \mathrm{l} \mathrm{L-glu-}$ tamine, and $10 \%(\mathrm{v} / \mathrm{v})$ heat-inactivated fetal bovine serum (Sigma, St Louis, Mo., USA). Around 200 islets were transplanted under the capsule of the left kidney using a capillary tube as described [11]. Four groups of transplantation were performed: from diabetic to normal (D-N) and from diabetic to diabetic (D-D), as well as from normal to normal (N-N) and from normal to diabetic rats (N-D). In some of the islet preparations from normal as well as from diabetic donors, groups of 30 islets were secured before transplantation for measurements of islet insulin and DNA contents [15]. In all recipient rats blood glucose levels (non-fasting) were measured both before and 4 weeks after islet transplantation.

\section{Kidney perfusion experiments}

Four weeks after transplantation, the rats were anaesthetized by i. p. injection of $50 \mathrm{mg} / \mathrm{kg}$ pentobarbital sodium. The graft bearing kidneys were isolated and perfused basically by the methods of Korsgren et al. [11]. Kidney perfusion was carried out at a constant flow rate of $2.5 \mathrm{ml} / \mathrm{min}$ maintained by a peristaltic pump. The medium used was Krebs-Henseleit bicarbonate buffer [16] supplemented with $20 \mathrm{~g} / \mathrm{l}$ bovine serum albumin (Sigma), $20 \mathrm{~g} / \mathrm{l}$ dextran T-70 (Pharmacia, Uppsala, Sweden) and $4.7 \mathrm{mmol} / \mathrm{lglu}$ cose. The Krebs-Henseleit bicarbonate buffer medium was kept at $37^{\circ} \mathrm{C}$ and continously gassed with a mixture of $95 \% \mathrm{O}_{2}$ and $5 \% \mathrm{CO}_{2}$. An equilibration period of $30 \mathrm{~min}$ was allowed before the start of perfusion with the test substances. The latter time point was designated as time 0 min. Stimulations with $27.8 \mathrm{mmol} / 1$ glucose and $10 \mathrm{mmol} / 1$ arginine were carried out with the aid of a side arm infusion pump. Effluents were collected at times indicated in the Figures into prechilled tubes containing aprotinin (Bayer, Leverkusen, Germany) at a final concentration of more than $500 \mathrm{KIE} / \mathrm{ml}$, and stored at $-20^{\circ} \mathrm{C}$ until insulin assay. At the end of perfusion, the islet grafts were dissected free from kidney parenchyma (but with kidney capsule still adhering), then frozen and stored in liquid nitrogen until extraction of RNA.

\section{Glucose and insulin assays}

Blood glucose determination was carried out by a glucose oxidase method using reagent strips (Boehringer Mannheim) read for absorbance in a reflectance meter (Boehringer Mannheim). IRI was measured by radioimmunoassay [17] using rat insulin as standard, ${ }^{125}$ I-labelled insulin as tracer, and our own antibodies raised against porcine insulin.

\section{RNA extraction and Northern blotting analysis}

Total RNA was extracted from the islet grafts by the guanidine isothiocyanate method [18]. After isolation, similar amounts of RNA $(0.8-1.0 \mu \mathrm{g})$ were applied to $1 \%$ agarose gels and electrophoresed. The RNA was then transferred to a nylon membrane (Magna Graph nylon transfer membrane; Micron Separation, Westboro, Mass., USA). The Northern blots were sequentially hybridized to ${ }^{32} \mathrm{P}$-labelled cDNA probes coding for rat insulin [PRI-7; 19] and mitochondrial encoded cytochrome b gene [20]. $\left[\alpha-{ }^{32} \mathrm{P}\right] \mathrm{dCTP}$ was obtained from Amersham (Amersham, Bucks., UK), and the probes were labeled using Multiprime DNA Labelling system (Amersham). Hybridization and autoradiography were performed as previously described [21]. Densitometric analysis of the autoradiograms was performed after non-saturating exposures with Quick Scan Jr densitometer (Helena Laboratories, Beaumont, Tx., USA). The values obtained were expressed in arbitrary units of O.D.

\section{Statistical analysis}

Results are expressed as mean \pm SEM. Integrated insulin responses were calculated as the increment above the secretion rates that were recorded immediately before the administration of test substances, and converted to mean secretion rates by division with certain time periods. Tests of significance were performed using the two-tailed Student's $t$-test for paired or unpaired differences. Multiple comparisons among groups were carried out using one-way analysis of variance and the Scheffe's test. 
Table 1. Characteristics of the islet donor and recipient rats

\begin{tabular}{|c|c|c|c|c|c|}
\hline \multicolumn{2}{|c|}{ Experimental groups } & \multirow{2}{*}{$\frac{\text { Age (weeks) }}{\text { At transplantation }}$} & \multirow{2}{*}{$\frac{\text { Body Weight }(\mathrm{g})}{\text { At transplantation }}$} & \multicolumn{2}{|l|}{ Blood Glucose (mmol/1) } \\
\hline & & & & Before transplantation & 4 weeks after transplantation \\
\hline \multicolumn{6}{|l|}{ Donors } \\
\hline Diabetic & (41) & $13.0 \pm 0.4$ & $168 \pm 3$ & $7.3 \pm 0.2^{\mathrm{a}}$ & \\
\hline \multicolumn{6}{|l|}{ Recipients } \\
\hline $\mathrm{D}-\mathrm{N}$ & (7) & $14.9 \pm 1.8$ & $309 \pm 25$ & $5.5 \pm 0.5$ & $4.9 \pm 0.3$ \\
\hline N-D & (10) & $15.7 \pm 1.1$ & $268 \pm 6^{d}$ & $11.4 \pm 0.6^{\mathrm{d}}$ & $9.7 \pm 0.6^{d}$ \\
\hline
\end{tabular}

The results are means \pm SEM of the number of observations indicated in parentheses. Female rats were used as islet donors, whereas male rats were used as recipients.

D-N, diabetic donor-normal recipient; D-D, diabetic donordiabetic recipient; N-N, normal donor-normal recipient; N-D, normal donor-diabetic recipient.

\section{Results}

\section{Characteristics of islet donor and recipient rats}

Body weights of diabetic recipients were significantly lower than those of normal recipients (Table 1 ). Diabetic recipients showed significantly higher levels of blood glucose than diabetic donors $(p<0.001)$. More severe diabetes in males ( = recipients) was expected from previous observations [22].

\section{Insulin and DNA contents in islets before transplantation}

The DNA content of islets from diabetic donor rats was decreased by $70 \%$, compared to normal rats: diabetic, $5.4 \pm 0.5(n=10)$; normal, $17.0 \pm 1.7$ (9) ng/islet, $p<0.0001$. Contents of insulin were also markedly reduced: diabetic, $31 \pm 4$ (10); normal, $104 \pm 10$ (9) $\mathrm{fmol} / \mathrm{ng}$ DNA, $p<0.0001$.

\section{Effects of transplantation on blood glucose and weight gain}

Hyperglycaemia in the diabetic recipients persisted after islet transplantation (Table 1). However, the blood glucose levels of N-D recipients decreased significantly after transplantation $(p<0.001$, paired Student's $t$ test), whereas D-D did not show such a decrease. The recipient rats in every group gained body weight to a similar extent after transplantation (results not shown).

\section{Insulin release from normal islet grafts}

Insulin release from the islet grafts of N-N and N-D is shown in Figure 1. During the equilibration period with $4.7 \mathrm{mmol} / \mathrm{l}$ of glucose alone, basal insulin secretion of

\footnotetext{
${ }^{\mathrm{a}} p<0.001$ vs normal donors;

${ }^{\mathrm{b}} p<0.01 ;{ }^{\mathrm{c}} p<0.001$ vs D-N;

${ }^{\mathrm{d}} p<0.001$ vs $\mathrm{N}-\mathrm{N}$.

Unpaired Student's $t$-test was used for comparisons
}

Table 2. Mean insulin secretion rates under basal and stimulative conditions with $27.8 \mathrm{mmol} / \mathrm{l}$ glucose or $10 \mathrm{mmol} / 1$ arginine

\begin{tabular}{llcc}
\hline $\begin{array}{l}\text { Experimental } \\
\text { groups }\end{array}$ & $\begin{array}{l}\text { Basal } \\
\text { (fmol/min) }\end{array}$ & $\begin{array}{l}\Delta \text { IRI glucose } \\
\text { (fmol/min) }\end{array}$ & $\begin{array}{l}\Delta \text { IRI arginine } \\
\text { (fmol/min) }\end{array}$ \\
\hline D-N (7) & $23.4 \pm 9.1$ & $-1.7 \pm 2.5$ & $34.9 \pm 10.2$ \\
D-D (7) & $25.1 \pm 8.3$ & $1.2 \pm 7.1$ & $95.0 \pm 23.7^{\mathrm{a}}$ \\
N-N (9) & $16.2 \pm 2.6$ & $96.2 \pm 29.0$ & $172.5 \pm 42.4$ \\
N-D (10) & $36.1 \pm 5.8^{\mathrm{c}}$ & $50.6 \pm 18.5$ & $336.1 \pm 62.6^{\mathrm{b}}$ \\
\hline
\end{tabular}

The results are means \pm SEM of the number of experiments indicated in parentheses. Experimental groups as in Table 1.

${ }^{a} p<0.05$ vs D-N;

${ }^{\mathrm{b}} p<0.05 ;{ }^{\mathrm{c}} p<0.01$ vs $\mathrm{N}-\mathrm{N}$

Unpaired Student's $t$-test was used for comparisons

$\mathrm{N}-\mathrm{D}$ was more than twice that of N-N (Table 2). There was a positive correlation between the blood glucose levels and basal insulin secretion in N-D $(r=0.6181)$ which was however not significant $(p=0.0568)$. Perfused kidneys from $\mathrm{N}-\mathrm{N}$ showed a biphasic pattern of insulin release in response to $27.8 \mathrm{mmol} / \mathrm{l}$ glucose. First phase insulin responses to glucose as assessed from the first $7 \mathrm{~min}$ of $27.8 \mathrm{mmol} / \mathrm{l}$ glucose did not significantly differ between N-N and N-D. There was a tendency for insulin secretion from N-D to be smaller than that from $\mathrm{N}-\mathrm{N}$ during the last $10 \mathrm{~min}$ of $27.8 \mathrm{mmol} / \mathrm{l}$ glucose $(p=$ 0.09 ). After cessation of glucose stimulation a small off-response was noted in N-D (Fig. 1). Thus, the insulin levels of N-D $3 \mathrm{~min}$ after cessation of $27.8 \mathrm{mmol} / \mathrm{lglu}$ cose were significantly higher than those at the last point of $27.8 \mathrm{mmol} / \mathrm{l}$ glucose infusion $(p<0.01$, paired Student's $t$-test). Concerning arginine stimulation, the islet grafts from N-D showed a 1.9-fold greater insulin response than the islet grafts from N-N (Fig. 1, Table 2).

\section{Insulin release from $n-S T Z$ islet grafts}

In perfused kidneys of D-D rats, there was a complete lack of insulin response to $27.8 \mathrm{mmol} / \mathrm{l}$ glucose (Fig. 2, Table 2). Arginine, on the other hand, evoked a 


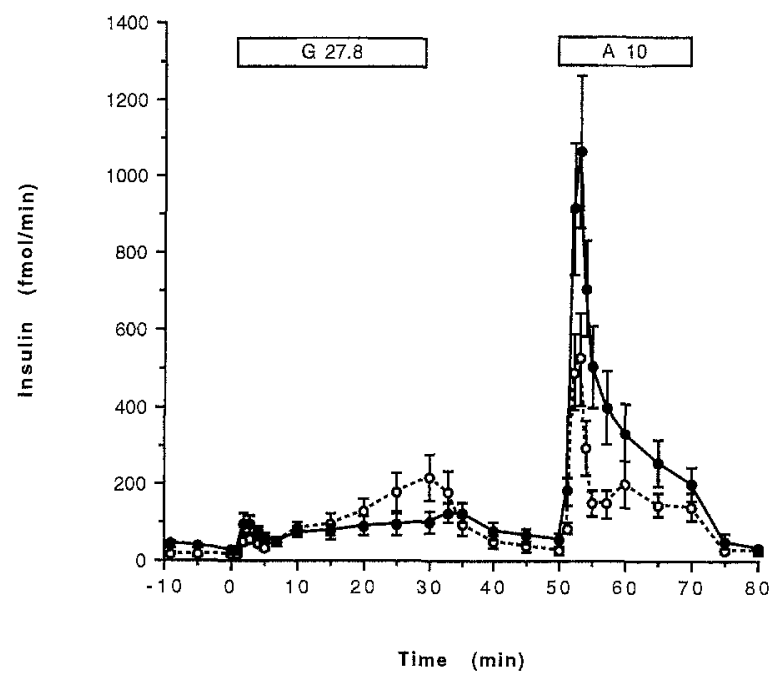

Fig. 1. Insulin release from the islet grafts of $N-N(O)$ and N-D (๑) in response to $27.8 \mathrm{mmol} / \mathrm{l}$ glucose and $10 \mathrm{mmol} / \mathrm{l}$ arginine 4 weeks after transplantation. Data are shown as mean \pm SEM of 9-10 experiments. Glucose concentration in the basal perfusate was $4.7 \mathrm{mmol} / 1$

marked insulin response in the presence of $4.7 \mathrm{mmol} / \mathrm{l}$ glucose (Fig. 2, Table 2).

Four weeks of normoglycaemia failed to restore any insulin response to glucose from transplants of D-N rats (Fig. 2, Table 2). As regards the response to arginine, this was reduced to $37 \%$ of the response in D-D rats. This influence of normoglycaemia vis-a-vis hyperglycaemia was not obviously dissimilar to that on normal islet grafts, the response in $\mathrm{N}-\mathrm{N}$ being $51 \%$ of that in N-D (Table 2).

\section{Measurements of $m R N A$}

Total RNA contents of the islet grafts (islets plus kidney capsule) did not differ significantly among the four groups (Table 3). In N-D mean insulin mRNA was reduced compared to $\mathrm{N}-\mathrm{N}$, but this difference did not reach statistical significance $(p=0.16)$. The results in nSTZ islet grafts were in marked contrast to those of normal ones. Thus the insulin mRNA was markedly and significantly reduced in $\mathrm{D}-\mathrm{N}$ compared to $\mathrm{D}-\mathrm{D}$ rats (Table 3). Measurements of cytochrome b mRNA showed no significant differences between $\mathrm{N}-\mathrm{N}$ and $\mathrm{N}-$ $\mathrm{D}$, nor between $\mathrm{D}-\mathrm{N}$ and $\mathrm{D}-\mathrm{D}$. However, the expression of cytochrome $b$ mRNA in islets exposed to n-STZ (groups D-N and D-D) was reduced by $70 \%$, compared to groups $\mathrm{N}-\mathrm{N}$ or $\mathrm{N}-\mathrm{D}$.

\section{Discussion}

The main aim of the present study was to investigate the long-term outcome of insulin secretion from islets of $n-S T Z$, after removing these islets from their original

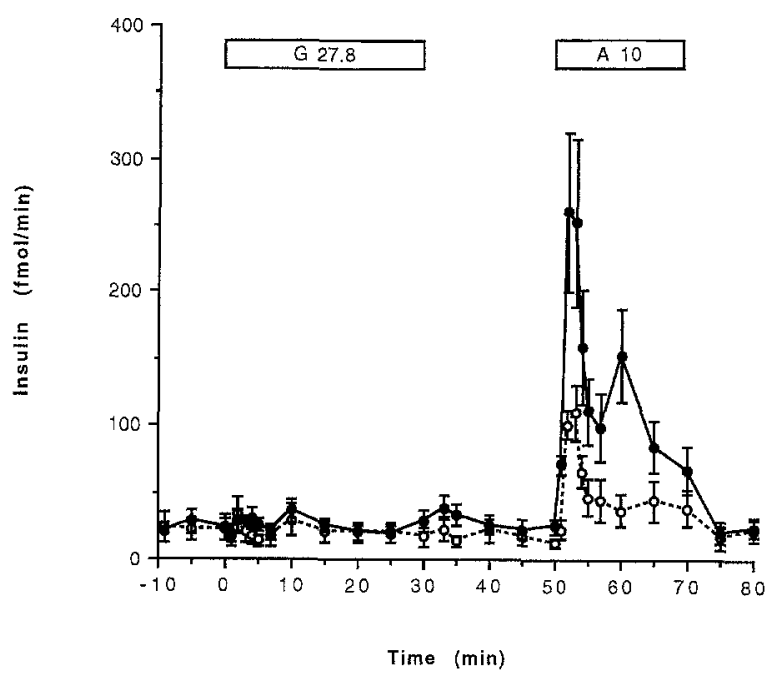

Fig.2. Insulin release from the islet grafts of D-N (O) and D-D (-) in response to $27.8 \mathrm{mmol} / \mathrm{l}$ glucose and $10 \mathrm{mmol} / 1$ arginine 4 weeks after transplantation. Data are shown as mean \pm SEM of seven experiments in each group. Glucose concentration in the basal perfusate was $4.7 \mathrm{mmol} / 1$

Table 3. Islet graft contents of total RNA and insulin and cytochrome b mRNA

\begin{tabular}{llcc}
\hline $\begin{array}{l}\text { Experimental } \\
\text { groups }\end{array}$ & $\begin{array}{l}\text { Total RNA } \\
(\mu \text { g/graft })\end{array}$ & $\begin{array}{l}\text { Insulin mRNA } \\
(\text { O.D. })\end{array}$ & $\begin{array}{r}\text { Cytochrome b } \\
\text { mRNA (O.D.) }\end{array}$ \\
\hline D-N & $1.6 \pm 0.6(7)$ & $60 \pm 24(7)$ & $413 \pm 147(5)$ \\
D-D & $2.4 \pm 0.6(6)$ & $496 \pm 119(5)^{\mathrm{a}}$ & $614 \pm 136(4)$ \\
N-N & $2.7 \pm 0.7(8)$ & $1565 \pm 242(8)$ & $1863 \pm 431(4)$ \\
N-D & $1.5 \pm 0.4(6)$ & $918 \pm 387(5)$ & $1487 \pm 182(5)$ \\
\hline
\end{tabular}

The results are means \pm SEM of the number of experiments indicated in the parenthesis. The contents of insulin and cytochrome $b$ mRNA were evaluated by densitometric scanning of the Northern blots, and the values are expressed in arbitrary units of O.D. Experimental groups as in Table 1.

${ }^{\mathrm{a}} p<0.01$ vs D-N using unpaired Student's $t$-test

and hyperglycaemic environment. To properly evaluate such an influence and to provide information on the validity of the transplantation protocol, we studied in parallel insulin secretion from islets isolated from nondiabetic rats. The transplanted islets from normal to normal rats showed a typical biphasic secretion of insulin in response to glucose, which was very similar to that of perfused pancreata of the Wistar rats [23]. Furthermore, the islet grafts from normal to diabetic rats showed somewhat reduced responses to glucose but enhanced responses to arginine. After cessation of glucose stimulation, off-responses of insulin were also observed. These findings are in good agreement with the pancreas perfusion studies of both spontaneously [24, 25] and experimentally-induced [26] hyperglycaemic rats.

The present study clearly shows that the insulin response to glucose from islets of $\mathrm{n}-\mathrm{STZ}$ diabetic rats is not restored by long-term normoglycaemia. Indeed 
not a trace of glucose-induced insulin secretion could be detected from n-STZ islets after 4 weeks of normoglycaemia. This lack of reversibility is in marked contrast to the situation in $48 \mathrm{~h}$ glucose-infused rats, in which secretory abnormalities are similar to those of n-STZ, but are completely reversible within $72 \mathrm{~h} \mathrm{[26].}$

Our experiments have also revealed that regulation by blood glucose of insulin mRNA is abnormal in nSTZ. Hence in islets from non-diabetic rats long-term hyperglycaemia tended to decrease insulin mRNA. These observations are in line with previous observations [27]. Conversely in n-STZ islets normoglycaemia markedly decreased the insulin gene expression. This paradoxical effect could be viewed as a second aspect of insensitivity to glucose at normoglycaemia; insensitivity thus encompassing two aspects of glucose regulation: that of insulin secretion and of insulin mRNA expression.

The results on arginine-induced insulin secretion on the other hand were qualitatively similar between nondiabetic and n-STZ islets in showing potentiation of the secretory response by hyperglycaemia. These findings agree with previous ones showing that correction of hyperglycaemia by insulin treatment decreased arginine-induced insulin secretion in n-STZ [7]. The molecular basis for preferential preservation of this aspect of glucose sensitivity is not known. A possibility that comes to mind relates to enhanced deposition of glycogen which is induced by hyperglycaemia [28]. Available energy may be rate-limiting for insulin responses to non-nutrient secretagogues, such as arginine. If so, the breakdown of enlarged glycogen stores could potentiate arginine-induced insulin secretion. Our results indicate that a putative fuel-providing mechanism is distinct from that by which the hexose per se initiates insulin secretion.

What is the cause of the irreversible beta-cell insensitivity in the n-STZ rat? Three different possibilities deserve consideration. First, long-term hyperglycaemia singly or in combination with other factors of an abnormal diabetic state could damage beta cells. Massive glucose infusions have been shown to kill beta cells and induce severe diabetes in dogs [29], but irreversibility of functional aberrations has not to our knowledge been demonstrated. In our n-STZ rats hyperglycaemia was generally mild prior to transplantation, casting some doubt on the impact of this factor for irreversibility. More importantly, the insulin response to glucose and insulin mRNA in islets from nondiabetic rats was at the most only moderately reduced after 4 weeks of hyperglycaemia. However we cannot rule out the possibility that hyperglycaemia occurring early in life, i. e. during the days after the neonatal injection of STZ, could have imparted an irreversible effect on beta-cell function.

Second, one can envisage that STZ has a long-lasting effect on the beta-cell function. A lasting sup- pressive effect of STZ on glucose-induced insulin secretion has been demonstrated in islets which had been cultured for 7 days after in vitro STZ treatment [30]. Such islets also released less insulin following transplantation [31]. It was also reported that islets isolated from n-STZ diabetic rats or treated in vitro with STZ showed a marked decrease in contents of mitochondrial DNA and expression of mitochondrial encoded cytochrome b mRNA [30,32]. These latter findings are compatible with the present observations of a lower content of cytochrome b mRNA in n-STZ than in normal islet grafts, although smaller amounts of islet tissue from the former could also underlie these differences. Since STZ has been reported to alkylate DNA and to induce DNA strand breaks [33], it is conceivable that a long-lasting effect of STZ is transmitted through mutations in DNA sequences. However, n-STZ islets are islets composed of mainly regenerated beta cells $[34,35]$, and it is unknown whether STZ effects on nuclear or mitochondrial DNA can be transmitted through progenitor cells to regenerated beta cells.

Third, the irreversible loss of a response to glucose at normoglycaemia could be due to selective elimination of beta cells possessing the lowest threshold to glucose. Such a notion is compatible with a documented heterogeneity of responsiveness to glucose among beta cells [36]. Heterogeneity pertains to glucose-induced insulin secretion [36,37], glucose-induced biosynthesis [38], as well as glucose oxidation [36,39]. The presence of glucose has been shown to decrease STZ toxicity [40]. It is conceivable that the glucose moiety of the STZ molecule could impart selective uptake of the toxin in glucose-sensitive cells. It is also possible that vulnerability of such cells could be indirectly related to handling of the toxin.

In summary, we have demonstrated that the loss of beta-cell sensitivity to glucose in $n-S T Z$ is irreversible during normoglycaemic conditions. Furthermore, nSTZ islet grafts exhibit a paradoxical decline in insulin mRNA upon normalization of blood glucose. The potentiating influence of hyperglycaemia on arginineinduced insulin secretion is however preserved. The cause of the irreversible insensitivity is not clear; however, two basic working hypotheses may be suggested: 1) STZ induces long-lasting genomic damage, especially at the mitochondrial level, rendering beta cells unable to respond to glucose with proper insulin secretion;2) STZ treatment at neonatal age selectively damages and eliminates a sub-population of glucose-sensitive cells, leaving less sensitive cells as progenitors of regenerating cells.

Acknowledgements. We are thankful to Drs. L.Jansson and O. Korsgren for helpful advice on the transplantation procedure. Secretarial help was provided by Ms. C. Ekehjelm. This study was supported by the Swedish Medical Research Council (grants no $04540 ; 12 x-9886,12 x-109$ ), the Swedish Diabetes Association, the Magnus Bergvall Foundation, the Nordic Insulin 
Foundation, the Juvenile Diabetes Foundation International, Funds of the Karolinska Institute, the Family Esn Eors Fund and the Hoechst Foundation. During his stay at the Karolinska Institute, Dr K. Inoue was the recipient of a stipend from the Wennergren Foundation. During her stay at the Department of Medical Cell Biology, Dr. M.Cetkovic-Cvrlje was the recipient of stipends from the Swedish Institute and the Faculty of Medicine, Uppsala University.

\section{References}

1. Weir GC, Leahy JL, Bonner-Weir S (1986) Experimental reduction of B-cell mass: implications for the pathogenesis of diabetes. Diabet Metab Rev 2: 125-161

2. Portha B, Blondel O, Serradas P et al. (1989) The rat models of non-insulin dependent diabetes induced by neonatal streptozotocin. Diabete Metab 15: 61-75

3. Portha B, Giroix M-H, Serradas P et al. (1988) Insulin production and glucose metabolism in isolated pancreatic islets of rats with NIDDM. Diabetes 37: 1226-1233

4. Giroix M-H, Rasschaert J, Bailbe D et al. (1991) Impairment of glycerol phosphate shuttle in islets from rats with diabetes induced by neonatal streptozocin. Diabetes 40: 227-232

5. Kergoat M, Bailbe D, Portha B (1987) Insulin treatment improves glucose-induced insulin release in rats with NIDDM induced by streptozocin. Diabetes 36: 971-977

6. Welsh N, Hellerström C (1990) In vitro restoration of insulin production in islets from adult rats treated neonatally with streptozotocin. Endocrinology 126: 1-7

7. Leahy JL, Bonner-Weir S, Weir GC (1985) Abnormal insulin secretion in a streptozocin model of diabetes: effects of insulin treatment. Diabetes 34: 660-666

8. Serradas P, Bailbe D, Portha B (1989) Long-term gliclazide treatment improves the in vitro glucose-induced insulin release in rats with type 2 (non-insulin-dependent) diabetes induced by neonatal streptozotocin. Diabetologia 32: 577584

9. Serradas P, Bailbe D, Blondel O, Portha B (1991) Abnormal $B$-cell function in rats with non-insulin-dependent diabetes induced by neonatal streptozotocin: effect of in vivo insulin, phlorizin, or vanadate treatments. Pancreas 6:54-62

10. Kruszynska YT, Villa-Komaroff L, Halban PA (1988) Islet B-cell dysfunction and the time course of recovery following chronic overinsulinisation of normal rats. Diabetologia 31: $621-626$

11. Korsgren O, Jansson L, Andersson A (1989) Effects of hyperglycemia on function of isolated mouse pancreatic islets transplanted under kidney capsule. Diabetes 38: $510-$ 515

12. Grill V, Westberg M, Östenson C-G (1987) B cell insensitivity in a rat model of non-insulin-dependent diabetes: evidence for a rapidly reversible effect of previous hyperglycemia. $\mathbf{J}$ Clin Invest 80: 664-669

13. Lacy PE, Kostianovsky M (1967) Method for the isolation of intact islets of Langerhans from the rat pancreas. Diabetes 16:35-39

14. Östenson C-G, Grill V (1986) Differences in long-term effects of L-glutamine and D-glucose on insulin release from rat pancreatic islets. Mol Cell Endocrinol 45: 215-221

15. Hinegardner RT (1971) An improved fluorometric assay for DNA. Anal Biochem 39: 197-201

16. Umbreit WW (1957) Methods for preparation and study of tissues. In: Umbreit WW, Burris RH, Stauffer JF (eds) Manometric techniques, Vol 1. Burgess Publishing Co., Minneapolis, pp 149-150
17. Herbert V, Lau K-S, Gottlieb CW, Bleicher SJ (1965) Coated charcoal immunoassay of insulin. J Clin Endocr 25: 13751384

18. Chirgwin JM, Przybyla AW, MacDonald RJ, Rutter WJ (1979) Isolation of biologically active ribonucleic acid from sources enriched in ribonuclease. Biochem 18: 5294-5299

19. Chan SJ, Noyes BE, Agarwal KL, Steiner DF (1979) Construction and selection of recombinant plasmids containing full-length complementary DNAs corresponding to rat insulin I and II. Proc Natl Acad Sci USA 76:5036-5040

20. Koike K, Kobayashi M, Yaginuma K, Taira M, Yoshida E, Imai M (1982) Nucleotide sequence and evolution of the rat mitochondrial cytochrome $b$ gene containing the other termination codon. Gene 20: 177-185

21. Eizirik DL, Björklund A, Cagliero E (1993) Genotoxic agents increase expression of growth arrest and DNA damage-inducible genes gadd 153 and gadd 45 in rat pancreatic islets. Diabetes 42: 738--745

22. Östenson C-G, Grill V, Roos M (1989) Studies on sex dependency of B-cell susceptibility to streptozotocin in a rat model of type II diabetes mellitus. Exp Clin Endocrinol 93: 241-247

23. Ogawa A, Johnson JH, Ohneda M et al. (1992) Roles of insulin resistance and $\beta$-cell dysfunction in dexamethasone-induced diabetes. J Clin Invest 90: 497-504

24. Portha B, Serradas P, Bailbe D, Suzuki K, Goto Y, Giroix M$H$ (1991) $\beta$-cell insensitivity to glucose in the GK rat, a spontaneous nonobese model for type II diabetes. Diabetes 40 : $486-491$

25. Östenson C-G, Khan A, Abdel-Halim SM et al. (1993) Abnormal insulin secretion and glucose metabolism in pancreatic islets from the spontaneously diabetic GK rat. Diabetologia $36: 3-8$

26. Leahy JL, Cooper HE, Deal DA, Weir GC (1986) Chronic hyperglycemia is associated with impaired glucose influence on insulin secretion: a study in normal rats using chronic in vivo glucose infusions. J Clin Invest 77: 908-915

27. Orland MJ, Chyn R, Permutt MA (1985) Modulation of proinsulin messenger RNA after partial pancreatectomy in rats: relationships to glucose homeostasis. J Clin Invest 75 : 2047-2055

28. Marynissen G, Leclercq-Meyer V, Sener A, Malaisse WJ (1990) Perturbation of pancreatic islet function in glucose-infused rats. Metabolism 39: 87-95

29. Imamura T, Koffler M, Helderman JH et al. (1988) Severe diabetes induced in subtotally depancreatized dogs by sustained hyperglycemia. Diabetes 37:600-609

30. Eizirik DL, Sandler S, Ahnström G, Welsh M (1991) Exposure of pancreatic islets to different alkylating agents decreases mitochondrial DNA content but only streptozotocin induces long-lasting functional impairment of B-cells. Biochem Pharmacol 42: 2275-2282

31. Eizirik DL, Sandler S, Korsgren O, Jansson L, Andersson A (1989) Persistent impairment of the insulin response to glucose both in vivo and in vitro after streptozotocin exposure: studies with grafted pancreatic islets and islets maintained in culture. Acta Endocrinol (Copenh) 121: 849-856

32. Welsh N, Pääbo S, Welsh M (1991) Decreased mitochondrial gene expression in isolated islets of rats injected neonatally with streptozotocin. Diabetologia 34: 626-631

33. Yamamoto H, Uchigata Y, Okamoto H (1981) Streptozotocin and alloxan induce DNA strand breaks and poly(ADPribose) synthetase in pancreatic islets. Nature 294: 284-286

34. Cantenys D, Portha B, Dutrillaux MC, Hollande E, Rozé C, Picon L (1981) Histogenesis of the endocrine pancreas in newborn rats after destruction by streptozotocin: an im- 
munocytochemical study. Virchows Arch [Cell Pathol] 35: 109-122

35. Dutrillaux MC, Portha B, Rozé C, Hollande E (1982) Ultrastructural study of pancreatic $B$ cell regeneration in newborn rats after destruction by streptozotocin. Virchows Arch [Cell Pathol] 39: 173-185

36. Pipeleers DG (1992) Heterogeneity in pancreatic $\beta$-cell population. Diabetes 41:777-781

37. Van Schravendijk CFH, Heylen L, Kiekens R, Pipeleers DG (1991) Heterogeneity in the secretory response of pancreatic B cells. Diabetes 40 [Suppl 1]:177A (Abstract)
38. Kiekens R, In't Veld P, Mahler T, Schuit F, Van De Winkel M, Pipeleers D (1992) Differences in glucose recognition by individual rat pancreatic $B$ cells are associated with intracellular differences in glucose-induced biosynthetic activity. J Clin Invest 89:117-125

39. De Vos A, Malaisse WJ, Kiekens R, Pipeleers D, Schuit F (1991) Pancreatic $\beta$ cells are heterogeneous in their capacity to metabolise glucose. Diabetologia 34 [Suppl 2]: A72 (Abstract)

40. Pipeleers D, Van De Winkel M (1986) Pancreatic B cells possess defense mechanisms against cell-specific toxicity. Proc Natl Acad Sci USA 83: 5267-5271 